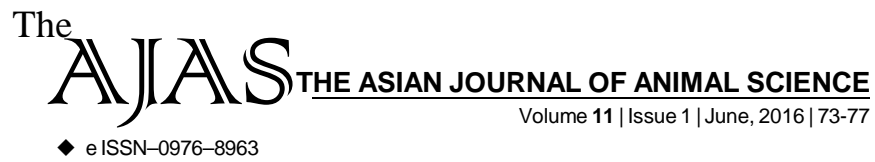

DOI : 10.15740/HAS/TAJAS/11.1/73-77 Visit us | www.researchjournal.co.in $\mathrm{S}$

A CASE STUDY

\title{
Constraints perceived by the small scale pig farmers in Sivasagar district of Assam: An analysis
}

RAFIQUL ISLAM, PHULESWAR NATH AND ARUNIMA BHARALI

(1,

Author for Corresponding -

\section{RAFIQUL ISLAM}

Krishi Vigyan Kendra, Dhubri, Bilasipara, DHUBRI (ASSAM)

INDIA

Email: drrafiqul.islam@aau.ac.in

See end of the article for

Coopted authors'
ABSTRACT...... A study was conducted covering eight development blocks of Sivasagar district to know the major constraints perceived by small scale pig farmers. Fifteen numbers of farmers from each block, thus, a total of one hundred twenty numbers of farmers were selected randomly on the basis of their experience in pig farming. Among the breeding factors, the highest mean score (68.98) was found in case of non-availability of improved breed and was ranked first. It was revealed that lack of knowledge of feeding balanced ration was the most important constraints with a mean score of 74.21 and was ranked first among feeding factors. The higher mortality of pig due to unidentified contagious diseases was the most serious constraints faced by the small scale pig farmers with a mean score of 67.33. Another important constraints faced by the farmers was lack of organized marketing facility with a mean score of 73.63. The social unacceptance of pig farmers (57.29) was also one of the major constraints faced by the pig farmers.

KEY WORDS...... Breeding, Constraints, Feeding, Health care, Marketing, Pig farming

HOW TO CITE THIS ARTICLE - Islam, Rafiqul, Nath, Phuleswar and Bharali, Arunima (2016). Constraints perceived by the small scale pig farmers in Sivasagar district of Assam: An analysis. Asian J. Animal Sci., 11(1): 73-77 (DOI : 10.15740/HAS/TAJAS/11.1/73-77).

ARTICLE CHRONICLE - Received : 10.03.2016; Accepted : 28.05.2016 